\title{
"Role of institutional quality in economic development: A case study of Asian
}

countries"

\begin{tabular}{ll} 
AUTHORS & $\begin{array}{l}\text { Oanh Kim Thi Tran (D) } \\
\text { Hac Dinh Le } \\
\text { Anh Hong Viet Nguyen (iD }\end{array}$ \\
\hline ARTICLE INFO & $\begin{array}{l}\text { Oanh Kim Thi Tran, Hac Dinh Le and Anh Hong Viet Nguyen (2021). Role of } \\
\text { institutional quality in economic development: A case study of Asian countries. } \\
\text { Problems and Perspectives in Management, 19(2), 357-369. } \\
\text { doi:10.21511/ppm.19(2).2021.29 }\end{array}$ \\
\hline DOI & http://dx.doi.org/10.21511/ppm.19(2).2021.29 \\
\hline RELEASED ON & Thursday, 24 June 2021 \\
\hline RECEIVED ON & Wednesday, 21 April 2021 \\
\hline ACCEPTED ON & Monday, 14 June 2021 \\
\hline LICENSE & $\begin{array}{l}\text { (co) EY } \\
\text { This work is licensed under a Creative Commons Attribution 4.0 International }\end{array}$ \\
\hline JOURNAL & License \\
\hline ISSN PRINT & "Problems and Perspectives in Management" \\
\hline ISSN ONLINE & 1727-7051 \\
\hline PUBLISHER & $1810-5467$ \\
\hline FOUNDER & LLC “Consulting Publishing Company "Business Perspectives" \\
\hline
\end{tabular}

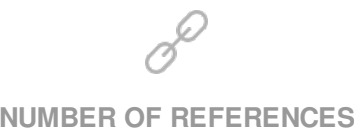

43
NUMBER OF FIGURES

2
NUMBER OF TABLES

6

(C) The author(s) 2021. This publication is an open access article. 


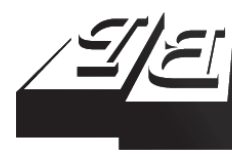

BUSINESS PERSPECTIVES

(O)

LLC "CPC "Business Perspectives" Hryhorii Skovoroda lane, 10 Sumy, 40022, Ukraine www.businessperspectives.org

Received on: $21^{\text {st }}$ of April, 2021 Accepted on: 14 ${ }^{\text {th }}$ of June, 2021 Published on: $24^{\text {th }}$ of June, 2021

(c) Oanh Kim Thi Tran, Hac Dinh Le, Anh Hong Viet Nguyen, 2021

Oanh Kim Thi Tran, Ph.D., Lecturer, Faculty of Banking and Finance, University of Finance - Marketing, Vietnam.

Hac Dinh Le, Ph.D., Lecturer, Faculty of Postgraduate Education, Banking University of Ho Chi Minh City, Vietnam.

Anh Hong Viet Nguyen, Ph.D., Lecturer, Faculty of Banking and Finance, University of Finance Marketing, Vietnam. (Corresponding author)

Oanh Kim Thi Tran (Vietnam), Hac Dinh Le (Vietnam),

Anh Hong Viet Nguyen (Vietnam)

\title{
ROLE OF INSTITUTIONAL QUALITY IN ECONOMIC DEVELOPMENT: A CASE STUDY OF ASIAN COUNTRIES
}

\begin{abstract}
The paper investigates the impact of institutional quality on economic growth by taking 48 countries in Asia between 2005 and 2018. By using the quantile regression methods with panel data, institutional quality is found to be a key factor of economic development. However, in the lower-income Asian countries, the institution with better quality appears to promote the growth more effectively than in the higher-income ones. Moreover, the paper also finds out a nonlinear relationship between institutions and economic growth. The results show that there is an institutional threshold for economic growth to reach its highest level. If the institution indicator exceeds the threshold, it causes the reverse effect on the growth. Moreover, the economic growth of Asian countries is also affected by inflation (INF), labor force (LABO), trade openness (OPEN), and infrastructure (TELE). From that, the study suggests some policy implications for Asian countries and Vietnam, in particular, in order to improve institutions contributing to economic growth.
\end{abstract}

Keywords

JEL Classification

\section{INTRODUCTION}

Economic growth is understood as an increase in the output (or income) of an economy in a certain period (Dung \& Phuong, 2009). In the domestic and international socio-economic context with certain advantages and challenges, economic growth is an important goal of each country's macroeconomic policy. The economic growth theory, therefore, aims to explain long-term economic growth and reveal a slight impact of institutions on economic growth, the biggest disadvantage of traditional growth theories (Nguyen, 2013). New institutional economics has been studied as a theory of economic growth. North (2020) commented that factors such as expanding markets, improving technology, and increasing human investment are all partly contributing to productivity, and a social institutional framework helps to create incentives, directly influencing economic and political activities and foundations for economic development. Bernabe (2017) studied sustainable economic development goals in Asian countries and pointed out that one of the economic development concerns is institutional and legal quality.

Aware of the significance of institutional improvement, leaders of the Ministry of Finance regularly pay attention and engage series of activities for institutional improvement in Vietnam, which consolidates to the national economic development targets in 2016-2020 (Ngo, 2020). Recognizing the national economic development goals and the impor- 
tant role of the institution in relation to economic growth. In recent years there are many domestic and foreign scientific studies in this field. Nakabashi et al. (2013), Alexiou et al. (2014), Acemoglu et al. (2014), Vianna and Mollick (2018), Salman et al. (2019), Ha (2016), Ngo and Nguyen (2020) concluded that institutions have positive impacts on economic growth. However, Dias and Tebaldi (2012) and Acemoglu et al. (2015) did not find a relationship between institutions and economic growth. Barro (1996) found a non-linear relationship between democracy and economic growth in which democracy can promote and negatively affect economic growth if it crosses a certain threshold. Law et al. (2013) supposed whether there is an institutional threshold for optimum economic growth, which is concerned by further studies. Marakbi and Turcu (2016), Ndjokou and Tsopmo (2017), and Ouoba and Sawadogo (2019) studied the role of institutions and concluded that there exists a threshold of institutions affecting economic growth while Chong (2020) found a non-linear relationship between institutional quality and economic growth. Thus, there is not complete research on the impact of institutions on economic growth, especially in Vietnam where institution related topic is relatively new.

Economic development management plays the primary role in any governmental commissions of countries and institutions, because it is one of the key factors influencing the growth. Therefore, it cannot be denied that studying the influence of institutional quality on economic growth is the vital target of all countries in the current context with the COVID-19 pandemic affecting the world's economic stability. The study results are the scientific basis to suggest some policy implications for improving the quality of institutions to promote economic growth in Asian countries including Vietnam.

\section{LITERATURE REVIEW AND HYPOTHESES}

According to North (1990), institutions are social rules of the game and their main role in a society is to reduce uncertainty by providing a structure for everyday life activities via human-human interaction guidelines such as greeting friends on streets, borrowing money, starting a company, etc. Without institutions, rules, or interaction guidelines, people can neither respond to one another nor follow their established agreements that allow individuals and legal entities to purchase, recruit people, and proceed with investments with the belief that contractual arrangements between parties are fulfilled (Kasper \& Streit, 1999).

Recently, several studies have been done on the relationship between institutions and economic growth following new institutional economic theory (NIE), state theory, institutional change theory, property rights theory, transaction cost theory, and Porter's theory; new institutional economic theory is a theoretical model, built on the old institutional economics theory that emphasizes that institutions are important factors for economic growth (Hodgson, 2004). By examining the relationship between economic institutions, political institutions, trade openness, and per capita in- come with OLS estimation techniques, Rigobon and Rodrik (2005) showed that both democracy and compliance with the law are good for economic performance and strongly impact income in the long run. It was indicated that countries with higher incomes have better institutions. Gani (2011) studied the effect of public governance and institutional quality framework on economic growth with a sample of 84 developing countries and showed that political stability and efficiency of the government have positive and significant effects on growth. Aisen and Veiga (2013) examined the effects of political instability on economic growth on a sample of 169 countries in 1960-2004 using GMM and indicated that political instability reduces per capita economic growth. Acemoglu et al. (2014) used panel data quantile regression with grouped fixed effects, 2SLS, and GMM to demonstrate that democratization increases about $20 \%$ GDP per capita in the long run. Di Vita (2017) studied the impact of institutional quality on economic growth in Italian regions using REM and Quantile Regressions Models (QRM) and pointed that complexity of regulation - time to decide civil disputes is an obstacle to the GDP growth of the region and per capita income. Vianna and Mollick (2018) investigated the economic development of 192 Latin American countries in 1996-2015 and found that each 0.1-point increase in institution- 
al quality results in $3.9 \%$ improvement in output per capita in Latin America. Acemoglu et al. (2015) found no causal relationship between income and democracy, in line with Jaunky (2013), who explored the relationship between democracy and economic growth in Africa using the VECM, GMM, FMOLS, and DOLS methods and showed that there are no impacts of democracy on growth and vice versa in the short term.

On the other hand, Marakbi and Turcu (2016) studied the impacts of institutional quality and corruption on the economic growth of 128 developed and developing countries in the period of 1984-2012 with a smooth transition table regression (PSTR) model and revealed that a non-linear relationship exists between corruption and economic growth with changes in institutional quality. Ndjokou and Tsopmo (2017) examined the relationship between institutional quality, natural resources, and economic growth in Sub-Saharan Africa and helped to determine the threshold of institutional quality in the relationship between natural resources and economic growth by the Panel Smoothness Transition Regression (PSTR) and GMM dynamic board model. Ouoba and Sawadogo (2019) defined an institutional threshold for government stability (index $>5.59$ ) and corruption (index $>1.3$ ) in relation to economic growth. Chong (2020) found a non-linear relationship between institutions and economic growth of the countries reaching the Trans-Pacific Partnership Agreement in 20022015 and better institutional quality helps to boost economic activities, and vice versa as the institutional quality exceeds the 0.638 threshold.

In Vietnam, Nguyen (2013) summarized theories of institutions and their importance to economic growth. Nguyen (2013) introduced a further point of view on institutions and the development of institutional economics. Nguyen and Nguyen (2014) assumed that the institutions play an important, even decisive role in the quality of economic growth and promoting innovation development process. Ngo and Nguyen (2020) examined the impact of total factor productivity (TFP) and institutional quality on the economic growth of 13 lower average income countries in Asia from 2000 to 2008 . With the regression method GMM, the study showed that factors of total productivity (TFP) have positive impacts while institutions have negative impacts on economic growth.

In general, studies on the impacts of institutions on economic growth have not reached a common conclusion. The existence of an institutional threshold affecting economic growth and a non-linear relationship between institutions and economic growth has been identified. However, there are not many studies on institutional thresholds and it is not clear whether there exist institutional thresholds affecting economic growth. Moreover, the institutionally related topic is quite new in Vietnam and none of the complete studies on institutions uses the quantile regression method. Hence, there are two primary objectives of this study. Firstly, it is crucial to determine the impacts of institutions on the economic growth of 48 Asian countries. Additionally, the difference of institution effects on economic development is explored using the quantile regression method compared with standard regression methods of panel data. Secondly, a non-linear relationship between institutions and economic growth is examined to identify the existence of an institutional threshold affecting economic growth in Asia. Consequently, based on the aims of the study, two hypotheses are suggested as follows:

\section{H1: Economic growth is positively influenced by institutions.}

\section{H2: There are non-linear relationships between institutions and economic growth.}

\section{METHODOLOGY}

To determine the impact of institutions on economic growth, the study uses some standard regression methods for panel data such as Pooled OLS, FEM, and REM regression, as well as carries out the Chow test and the Hausman test to choose the most appropriate estimation method. However, the outcomes revealed that there are models with heteroscedasticity and autocorrelation. Therefore, the FGLS method is executed, as proposed by Beck and Katz (1995), to improve the effectiveness of the estimation. In addition, the Breusch-Pagan test showed heterogeneous error variance of the FEM model is inconsistent, so the use of the quantile 
regression method, introduced by Koenker and Bassett (1978), to study the economic situation for several quantiles is suitable. Moreover, the sample consists of Asian countries with different levels of economic, financial, social as well as political development. Consequently, the quantile regression is the more suitable method to explore the different impacts of institutions on economic growth relating to several quantiles of economic performance in the sample. The results from quantile regression are compared with the FGLS method showing that whether the effect of institutional quality on quantiles of economic performance is different from the mean value or not.

Although quantile regression can be performed in detail from 0.01 to 0.99 , basic quantiles of the ef- ficiency variable distribution function are chosen for analysis, including the quantiles of $0.1,0.25$, 0.5 , and 0.75 due to the scope of study and relevant sample features.

The study further tests the non-linear relationship between institutions and economic growth by adding squared institutional variables to the model and using panel data regression methods. However, the results of the model defect tests have heteroscedasticity and autocorrelation. Therefore, general least squares regression (FGLS) for nonlines on the panel data is used, as proposed by Beck and Katz (1995).

Based on empirical studies and theories, study model factors include institutional quality, expenditure of the government, total domestic in-

Table 1. Synthesis of variables in the model

Source: Authors' elaboration.

\begin{tabular}{|c|c|c|c|c|}
\hline Symbol & Description & Previous studies & Hypothesis & $\begin{array}{l}\text { Data } \\
\text { resource }\end{array}$ \\
\hline \multicolumn{5}{|c|}{ Dependent variable } \\
\hline GDP & $\begin{array}{l}\text { Real GDP per capita, taking natural } \\
\text { logarithms }\end{array}$ & $\begin{array}{l}\text { Miller and Upadhyay (2002); Loko and } \\
\text { Diouf (2009); Law et al. (2013); Di Vita } \\
\text { (2017); Ngo and Nguyen (2020) }\end{array}$ & & World Bank \\
\hline \multicolumn{5}{|c|}{ Explanation variables } \\
\hline INS & $\begin{array}{l}\text { Overall CPIA Index or IDA resource } \\
\text { allocation index ( } 1=\text { low to } 6=\text { high })\end{array}$ & & + & World Bank \\
\hline CPIA_PUBS & $\begin{array}{l}\text { CPIA public sector management and } \\
\text { institutions cluster average ( } 1=\text { low to } \\
6=\text { high) }\end{array}$ & & + & World Bank \\
\hline CPIA_SOCl & $\begin{array}{l}\text { CPIA policies for social inclusion/ } \\
\text { equity cluster average (1=low to } \\
6 \text { =high) }\end{array}$ & & + & World Bank \\
\hline CPIA_STRC & $\begin{array}{l}\text { CPIA structural policies cluster } \\
\text { average ( } 1=\text { low to } 6=\text { high })\end{array}$ & & + & World Bank \\
\hline CPIA_ECON & $\begin{array}{l}\text { CPIA economic management cluster } \\
\text { average ( } 1=\text { low to } 6=\text { high) }\end{array}$ & & + & World Bank \\
\hline \multicolumn{5}{|c|}{ Control variables } \\
\hline GEXP & $\begin{array}{l}\text { Government expenditure, by a } \\
\text { percentage of the GDP }\end{array}$ & $\begin{array}{c}\text { Loko and Diouf (2009); Siddiqui and } \\
\text { Ahmed (2013); Di Vita (2017); Ngo and } \\
\text { Nguyen (2020) }\end{array}$ & & World Bank \\
\hline TINV & $\begin{array}{l}\text { Total domestic investment, by a } \\
\text { percentage of the GDP }\end{array}$ & $\begin{array}{l}\text { Loko and Diouf (2009); Ismihan and } \\
\text { Metin-Ozcan (2009); Alani (2012); Erum } \\
\text { et al. (2016); Ha (2016); Ngo and Nguyen } \\
\text { (2020) }\end{array}$ & & $\begin{array}{l}\text { World Bank } \\
\quad \& \text { IMF }\end{array}$ \\
\hline OPEN & $\begin{array}{l}\text { Trade openness average, by a } \\
\text { percentage of the GDP }\end{array}$ & $\begin{array}{l}\text { Loko and Diouf (2009); Siddiqui and } \\
\text { Ahmed (2013); Ngo and Nguyen (2020) }\end{array}$ & & World Bank \\
\hline LABO & Labor force, taking natural logarithms & $\begin{array}{l}\text { Miller and Upadhyay (2002), Ha (2016); Di } \\
\qquad \text { Vita (2017); Ngo and Nguyen (2020) }\end{array}$ & & World Bank \\
\hline INF & Inflation rate & $\begin{array}{l}\text { Loko and Diouf (2009); Ngo and Nguyen } \\
\qquad(2020)\end{array}$ & & $\begin{array}{l}\text { World Bank } \\
\quad \& I M F\end{array}$ \\
\hline TELE & Quality of infrastructure & $\begin{array}{l}\text { Loko and Diouf (2009); Slesman et al. } \\
\text { (2015); Di Vita (2017); Ngo and Nguyen } \\
\qquad(2020)\end{array}$ & & World Bank \\
\hline
\end{tabular}


vestment, trade openness, workforce, inflation rate, and infrastructure. Each factor is represented by an independent variable in the model excepting institutional quality, which uses an index of institutional and policy assessment of a country (CPIA - Country Policy and Institutional Assessment) annually published by the World Bank. There are five indicators extracted from the CPIA set of indicators published by the World Bank to measure institutions, which are used: (i) INS (Overall CPIA Index or IDA resource allocation index); (ii) CPIA_PUBS (CPIA public sector management and institutions cluster D average); (iii) CPIA_SOCI (CPIA policies for social inclusion/ equity cluster $\mathrm{C}$ average); (iv) CPIA_STRC (CPIA structural policies cluster B average); (v) CPIA ECON (CPIA economic management cluster A average).

The paper uses the balanced panel data of 48 Asian countries for the period 2005-2018. Therefore, the article has $48 \times 14=672$ observations. Table 1 explains the variables present in the regression model and the basis of the respective variables included in the model:

\subsection{Model}

The study builds a multiple regression model on static panel data to analyze the institutional impact on economic growth inherited from Miller and Upadhyay (2002), Loko and Diouf (2009), Di Vita (2017), and Pham (2017). There are five linear regression models of the institutional impact on economic growth which are relevant to five explanatory variables extracted from the World Bank CPIA index as below:

$$
\begin{aligned}
& G D P_{i t}=\beta_{0}+\beta_{1} I N S_{i t}+\beta_{2} G E X P_{i t}+ \\
& +\beta_{3} T I N V_{i t}+\beta_{4} I N F_{i t}+\beta_{5} L A B O_{i t}+ \\
& +\beta_{6} T E L E_{i t}+\beta_{7} O P E N_{i t}+\mu_{i}+e_{i t} . \\
& G D P_{i t}=\beta_{0}+\beta_{1} C P I A_{-} P U B S_{i t}+\beta_{2} G E X P_{i t}+ \\
& +\beta_{3} T I N V_{i t}+\beta_{4} I N F_{i t}+\beta_{5} L A B O_{i t}+ \\
& +\beta_{6} T E L E_{i t}+\beta_{7} O P E N_{i t}+\mu_{i}+e_{i t} . \\
& G D P_{i t}=\beta_{0}+\beta_{1} C P I A_{-} S O C I_{i t}+\beta_{2} G E X P_{i t}+ \\
& +\beta_{3} T I N V_{i t}+\beta_{4} I N F_{i t}+\beta_{5} L A B O_{i t}+ \\
& +\beta_{6} T E L E_{i t}+\beta_{7} O P E N_{i t}+\mu_{i}+e_{i t} .
\end{aligned}
$$

$$
\begin{aligned}
& G D P_{i t}=\beta_{0}+\beta_{1} C P I A_{-} E C O N_{i t}+\beta_{2} G E X P_{i t}+ \\
& +\beta_{3} T I N V_{i t}+\beta_{4} I N F_{i t}+\beta_{5} L A B O_{i t}+ \\
& +\beta_{6} T E L E_{i t}+\beta_{7} O P E N_{i t}+\mu_{i}+e_{i t} .
\end{aligned}
$$

With $i=1,2, . ., N ; t=1,2, \ldots$; $\mathrm{T}$ (i means the country and $\mathrm{t}$ means the observed time in the model); $\mu_{i}$ is country fixed effect and independently distributed similar errors $e_{i t} \approx i . i . d\left(0, \delta_{e}^{2}\right)$, ; $E=\left(\mu_{i} / e_{i t}\right)=0$.

Barro (1996) and Chong (2020) found a nonlinear relationship between institutional quality and economic growth. This means that institutional quality can promote economic growth until it gets a certain threshold, continuing to improve the quality of institutions might reduce economic growth. Therefore, an "inverted $U$-shaped" relationship between institutional quality and economic growth is found by Chong (2020). To test the nonlinear relationship between institutional quality and economic growth, this study uses quadratic functions. Hence, squared institutional variables were added to the models (1), (2), (3), (4), and (5) to obtain the models as below:

$$
\begin{aligned}
& G D P_{i t}=\beta_{0}+\beta_{1} I N S_{i t}+\beta_{2} \cdot I N S_{i t}^{2}+ \\
& +\beta_{3} G E X P_{i t}+\beta_{4} T I N V_{i t}+\beta_{5} I N F_{i t}+ \\
& +\beta_{6} L A B O_{i t}+\beta_{7} T E L E_{i t}+ \\
& +\beta_{8} O P E N_{i t}+\mu_{i}+e_{i t} .
\end{aligned}
$$

$$
\begin{aligned}
& G D P_{i t}=\beta_{0}+\beta_{1} C P I A_{-} P U B S_{i t}+ \\
& +\beta_{2} \cdot C P I A_{-} P U B S_{i t}^{2}+\beta_{3} G E X P_{i t}+ \\
& +\beta_{4} T I N V_{i t}+\beta_{5} I N F_{i t}+\beta_{6} L A B O_{i t}+ \\
& +\beta_{7} T E L E_{i t}+\beta_{8} O P E N_{i t}+\mu_{i}+e_{i t} .
\end{aligned}
$$

$$
\begin{aligned}
& G D P_{i t}=\beta_{0}+\beta_{1} C P I A_{-} S O C I_{i t}+ \\
& +\beta_{2} \cdot C P I A_{-} S O C I_{i t}^{2}+\beta_{3} G E X P_{i t}+ \\
& +\beta_{4} T I N V_{i t}+\beta_{5} I N F_{i t}+\beta_{6} L A B O_{i t}+ \\
& +\beta_{7} \text { TELE }_{i t}+\beta_{8} O P E N_{i t}+\mu_{i}+e_{i t} \text {. }
\end{aligned}
$$




$$
\begin{aligned}
& G D P_{i t}=\beta_{0}+\beta_{1} C P I A_{-} \text {STRC }_{i t}+ \\
& +\beta_{2} \cdot C P I A_{-} S T R C_{i t}^{2}+\beta_{3} G E X P_{i t}+ \\
& +\beta_{4} T I N V_{i t}+\beta_{5} I N F_{i t}+\beta_{6} L A B O_{i t}+ \\
& +\beta_{7} T E L E_{i t}+\beta_{8} O P E N_{i t}+\mu_{i}+e_{i t} \cdot \\
& G D P_{i t}=\beta_{0}+\beta_{1} C P I A_{-} E C O N_{i t}+ \\
& +\beta_{2} \cdot C P I A_{-} E C O N_{i t}^{2}+\beta_{3} G E X P_{i t}+ \\
& +\beta_{4} T I N V_{i t}+\beta_{5} I N F_{i t}+\beta_{6} L A B O_{i t}+ \\
& +\beta_{7} T E L E_{i t}+\beta_{8} O P E N_{i t}+\mu_{i}+e_{i t} .
\end{aligned}
$$

\section{RESULTS}

Firstly, after using Pooled, FEM, and REM methods to carry out regression data of 48 Asian countries in the period 2005-2018 with 672 observations and tests, the FGLS regression method is applied to improve the efficiency of the estimation. To show the relationship between institutions and economic growth, the study examines the impact of institutions at different quantiles of income per capita (GDP) and its results from five models corresponding to institutional variables of INS, CPIA_PUBS, CPIA_SOCI, CPIA_STRC, CPIA_ECON summarized in Table 2 as follows:

Considering the expected value of economic growth using FGLS, the study shows that factors of institutional quality have a statistically significant impact on the economic growth of Asian countries (GDP), and results of INS, CPIA_PUBS, CPIA_ SOCI, and CPIA_ECON are consistent with the hypotheses. In addition, they support Rodrik et al. (2004), Rigobon and Rodrik (2005), Venard (2013), Siddiqui and Ahmed (2013), Nakabashi et al. (2013), Acemoglu et al. (2014), Alexiou et al. (2014), Vianna and Mollick (2018), Salman et al. (2019), meaning that institutions have positive impacts on economic growth. Particularly, negative impacts of the variable CPIA_STRC on GDP are found with a negative regression coefficient and statistically significant at the expected value, different from the hypothesis but consistent with Ngo and Nguyen (2020). However, it is noted that the level and direction of impact of these factors are different at different quantiles.

As summarized in Table 2, the effect of variable INS on economic growth has significant meaning at most of the quantiles, except for the quantile 0.5, which coefficient INS is not statistically significant while positive impacts of public and institutional management quality variables (CPIA_PUBS) on economic growth with significance level at only low quantiles of 0.1 and 0.25 . The effects of CPIA_STRC and CPIA_ECON on the GDP are both positive and have statistically significant levels at a quantile of 0.1 while the opposite trend is found at the other higher quantiles. The impact of CPIA_SOCI on economic growth is the strongest because of its largest coefficient compared to other variables representing institutions affecting the GDP. It is indicated that the direction of the impact of social inclusion/equity policy quality on economic growth is positive and significant across all GDP quantiles, but its level decreases at higher quantiles. Therefore, the impact of institution quality on economic performance is not the same at different quantiles. In general, the impact of institutions is usually positive at low quantiles of the GDP while that is reversed when the GDP gets higher quantiles.

\begin{tabular}{|c|c|c|c|c|c|c|}
\hline \multirow{2}{*}{ Variables } & \multirow{2}{*}{ Expectations } & \multirow{2}{*}{ FGLS regression } & \multicolumn{4}{|c|}{ Quantile regression } \\
\hline & & & 0.1 & 0.25 & 0.5 & 0.75 \\
\hline INS & + & $0.419^{* * *}$ & $0.408^{* *}$ & $0.402^{* * *}$ & -0.153 & $-0.815^{* * *}$ \\
\hline CPIA_PUBS & + & $0.409 * * *$ & $0.468^{* * *}$ & $0.591^{* * *}$ & 0.19 & -0.167 \\
\hline CPIA_SOCI & + & $0.521^{* * *}$ & $0.755^{* * *}$ & $0.769 * * *$ & $0.689 * * *$ & $0.689 * * *$ \\
\hline CPIA_STRC & + & $-0.186 * * *$ & $0.190 * * *$ & -0.0767 & $-0.300 * * *$ & $-0.708^{* * *}$ \\
\hline CPIA_ECON & + & $0.105^{* *}$ & $0.124^{*}$ & 0.11 & -0.0992 & $-0.327 * * *$ \\
\hline
\end{tabular}

Secondly, the FGLS regression method is used to examine the non-relationship between institutional quality and economic growth. The results of regression models (6); (7); (8); (9) and (10) are presented in Table 3.

Table 2. Synthesis of results on the impact of institutions on economic growth in Asian countries

Source: Authors' elaboration.

Note: ${ }^{* *}$ means $\mathrm{p}<0.01 ;{ }^{* *}$ means $\mathrm{p}<0.05$; and ${ }^{*}$ means $\mathrm{p}<0.1$. 

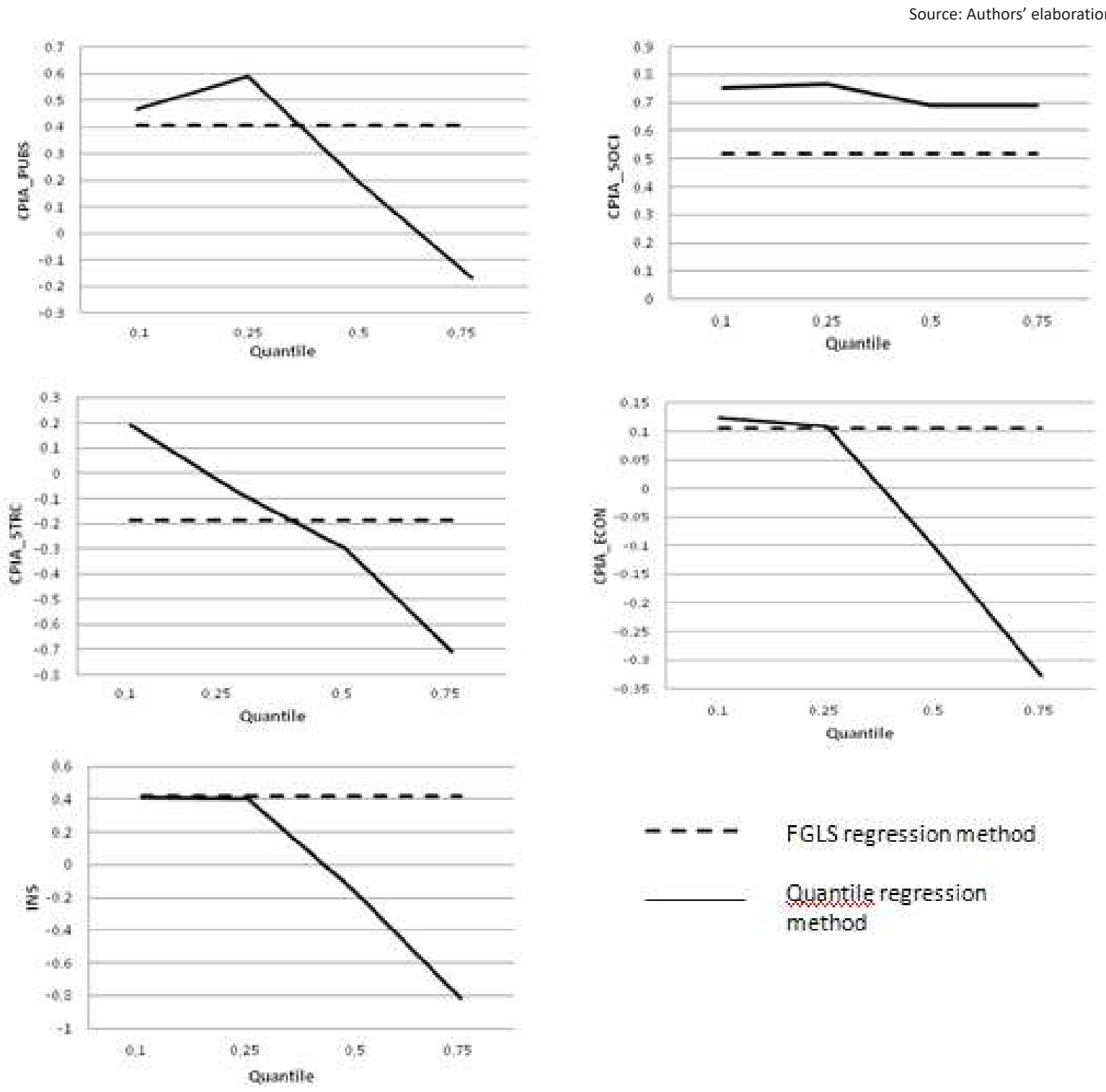

Figure 1. Regression coefficients of the institutional variables based on the FGLS regression and quantile regression methods

Regression coefficients of variables related to institutions and squared institutions such as INS, INS ${ }^{2}$, CPIA_PUBS, CPIA_PUBS ${ }^{2}$, CPIA_SOCI, CPIA_SOCI ${ }^{2}$,CPIA_STRC, CPIA_STRC ${ }^{2}$ are statistically significant except for the coefficient of CPIA_ECON and CPIA_ECON ${ }^{2}$ in the regression model (10). It is shown that there is a non-linear relationship between the institution and economic growth for institutional variables of INS, CPIA PUBS, CPIA_SOCI, and CPIA_STRC, implying the existence of a non-linear relationship between institutions and economic growth, consistent with Chong (2020). From that, the study determines the institutional threshold for maximizing average per capita GDP income based on the regres- sion coefficients that are statistically significant in models (6), (7), (8), and (9).

The threshold of INS is found considering the first derivative of both sides with INS as $G D P=\beta_{1}+2 \beta_{2} \cdot I N S$. To find the highest value of the GDP, the first derivative of the GDP is 0 . Therefore, the highest value of the GDP is $\Delta=\beta_{1} /-2 \beta_{2}$. With $\beta_{1}=8.696>0$ and $\beta_{1}=-1.201<0$, the GDP is at the highest when the quality of the institution (INS) reaches 3.620. This means economic growth is driven by the improvement of institutional quality (INS) shown by an increase in overall CPIA score up to 3.62 at which the economic growth is maxi- 
Table 3. Results of FGLS method for models (6), (7), (8), (9) and (10)

\begin{tabular}{|c|c|c|c|c|c|}
\hline Variables & (6) & (7) & (8) & (9) & (10) \\
\hline \multirow{2}{*}{ GEXP } & -0.00132 & -0.00438 & -0.00099 & -0.00601 & $-0.00784^{*}$ \\
\hline & {$[-0.29]$} & {$[-0.96]$} & {$[-0.22]$} & {$[-1.29]$} & {$[-1.74]$} \\
\hline \multirow{2}{*}{ TINV } & -0.00236 & -0.00285 & -0.00238 & -0.00406 & -0.00205 \\
\hline & {$[-0.79]$} & {$[-0.96]$} & {$[-0.79]$} & {$[-1.33]$} & {$[-0.67]$} \\
\hline \multirow{2}{*}{ INF } & $-0.0105^{* * *}$ & $-0.00983^{* * *}$ & $-0.00987 * * *$ & $-0.0128^{* * *}$ & $-0.0128^{* * *}$ \\
\hline & {$[-2.99]$} & {$[-2.93]$} & {$[-3.07]$} & {$[-3.39]$} & {$[-3.43]$} \\
\hline \multirow{2}{*}{ LABO } & $-0.166^{* * *}$ & $-0.152^{* * *}$ & $-0.137^{* * *}$ & $-0.169 * * *$ & $-0.161^{* * *}$ \\
\hline & {$[-9.24]$} & {$[-8.37]$} & {$[-7.11]$} & {$[-9.65]$} & {$[-8.89]$} \\
\hline \multirow{2}{*}{ TELE } & $0.217^{* * *}$ & $0.183^{* * *}$ & $0.185^{* * *}$ & $0.278^{* * *}$ & $0.252 * * *$ \\
\hline & {$[9.61]$} & {$[8.08]$} & {$[8.16]$} & [11.44] & {$[10.45]$} \\
\hline \multirow{2}{*}{ OPEN } & $0.00421 * * *$ & $0.00445^{* * *}$ & $0.00436^{* * *}$ & $0.00359 * * *$ & $0.00434^{* * *}$ \\
\hline & [7.85] & [8.57] & [8.23] & [6.55] & [7.82] \\
\hline \multirow{2}{*}{ INS } & $8.696 * * *$ & & & & \\
\hline & [8.03] & & & & \\
\hline \multirow{2}{*}{$\mathrm{INS}^{2}$} & $-1.201^{* * *}$ & & & & \\
\hline & {$[-7.92]$} & & & & \\
\hline \multirow{2}{*}{ CPIA_PUBS } & & $3.997 * * *$ & & & \\
\hline & & {$[4.60]$} & & & \\
\hline \multirow{2}{*}{ CPIA_PUBS ${ }^{2}$} & & $-0.583^{* * *}$ & & & \\
\hline & & {$[-4.20]$} & & & \\
\hline \multirow{2}{*}{ CPIA_SOCl } & & & $4.548^{* * *}$ & & \\
\hline & & & {$[4.22]$} & & \\
\hline \multirow{2}{*}{ CPIA_SOCl ${ }^{2}$} & & & $-0.584^{* * *}$ & & \\
\hline & & & {$[-3.77]$} & & \\
\hline \multirow{2}{*}{ CPIA_STRC } & & & & $2.707^{* * *}$ & \\
\hline & & & & {$[4.57]$} & \\
\hline \multirow{2}{*}{ CPIA_STRC 2} & & & & $-0.407 * * *$ & \\
\hline & & & & {$[-4.80]$} & \\
\hline \multirow{2}{*}{ CPIA_ECON } & & & & & 0.301 \\
\hline & & & & & [1.09] \\
\hline \multirow{2}{*}{ CPIA_ECON ${ }^{2}$} & & & & & -0.0261 \\
\hline & & & & & {$[-0.73]$} \\
\hline \multirow{2}{*}{ _cons } & $-5.523^{* * *}$ & $3.203 * *$ & 0.945 & $5.653^{* * *}$ & $9.151^{* * *}$ \\
\hline & {$[-2.86]$} & {$[2.31]$} & {$[0.50]$} & [5.28] & {$[16.44]$} \\
\hline N & 672 & 672 & 672 & 672 & 672 \\
\hline
\end{tabular}

Note: Standard errors in parentheses. ${ }^{* * *}$ means $p<0.01 ;{ }^{* *}$ means $p<0.05$; and ${ }^{*}$ means $p<0.1$.

mized and reduced when the score is over the threshold.

Similarly, thresholds of variables CPIA_PUBS, CPIA_SOCI, and CPIA_STRC are also found by considering the first derivative of both sides with CPIA_PUBS, CPIA_SOCI, and CPIA_STRC: $\Delta=\beta_{1} /-2 \beta_{2}$, with the corresponding regression coefficients in Table 3, the thresholds of CPIA_PUBS, CPIA_SOCI, and CPIA_STRC are $3.428,3.894$, and 3.326 respectively for the highest GDP value. Coefficients of CPIA_ECON and CPIA_ECON ${ }^{2}$ are found not statistically significant in model (10). It is concluded that there is no existence of an institutional threshold in relation to economic growth with the institution measured by the variable of CPIA_ECON.

Therefore, Table 4 summarizes the results on non-linear relationships between institutions and economic growth in five models corresponding to five different institutional variables measured by CPIA indicators. The results show that there are non-linear relationships in four cases, in which institutional variables measured by INS, CPIA PUBS, CPIA_STRC, CPIA_SOCI indicators as well as the value of institutional thresholds are found corresponding to four cases. 
Table 4. Institutional thresholds affecting economic growth in Asia

Source: Authors' elaboration.

\begin{tabular}{|c|c|c|c|c|c|}
\hline \multirow{2}{*}{ Variables } & \multicolumn{5}{|c|}{ The value of institutional thresholds (X) } \\
\hline & $1 \leq X \leq 3.326$ & $3.326<X \leq 3.428$ & $3.428<X \leq 3.62$ & $3.62<X \leq 3.894$ & $3.894<X \leq 6$ \\
\hline INS & + & + & + & - & - \\
\hline CPIA_PUBS & + & + & - & - & - \\
\hline CPIA_SOCI & + & + & + & + & - \\
\hline CPIA_STRC & + & - & - & - & - \\
\hline
\end{tabular}

Note: The sign $(+)$ represents a positive change with the GDP, the sign (-) represents a negative change with the GDP.

\section{DISCUSSION}

The results shown in Table 2 indicate that economic growth in Asia is affected by institutions as all of regression coefficients in the the models are statistically significant. However, only institutional quality about structural policies has negative impact on economic development while the others support the first hypothesis (H1). These inventions prove that not all aspects of institutions always promote economic growth in Asia. On the other hand, the results in Table 3 agree with the second hypothesis (H2), except the case of institutional quality measured by CPIA_ECON variable. There is no evidence of a nonlinear relationship between institutions about economic management and economic growth in Asia because the regression coefficients of both CPIA_ECON and CPIA_ECON2 variables in model (10) are not statistically significant.

As shown in Figure 2, the overall average institutional quality (INS) of Vietnam is higher than that of Asian countries between 2005 and 2018, but its overall CPIA scores sharply reduce from 3.74 in
2005 to 3.57 in 2018, total deduction of 0.17 point while the average Asian countries only decrease by 0.03 point.

Vietnam's economic growth has always been in the 0.25 quantile among Asian countries during 2005-2018 as shown in Table 5. Consequently, the results show that Vietnam needs to improve institutional quality in terms of social inclusion/equity as well as public and institutional management policies to promote economic growth because variables of CPIA_PUBS and CPIA_SOCI are statistically significant and positive $(>0)$. Coefficients of the CPIA_ECON variable as well as CPIA_STRC variable are not statistically significant at the quantile of 0.25 following the regression results of the impacts of institutions on Asian economic growth at the different distribution of economic performance.

CPIA scores of Vietnam in 2018 in Table 6 reveals that the score CPIA_PUBS of 3.50 exceeds the threshold of CPIA_PUBS (3.428) and the score of CPIA_SOCI of Vietnam in 2018 at 3.70 is lower than the CPIA_SOCI threshold of 3.894 .

Source: Authors' elaboration.

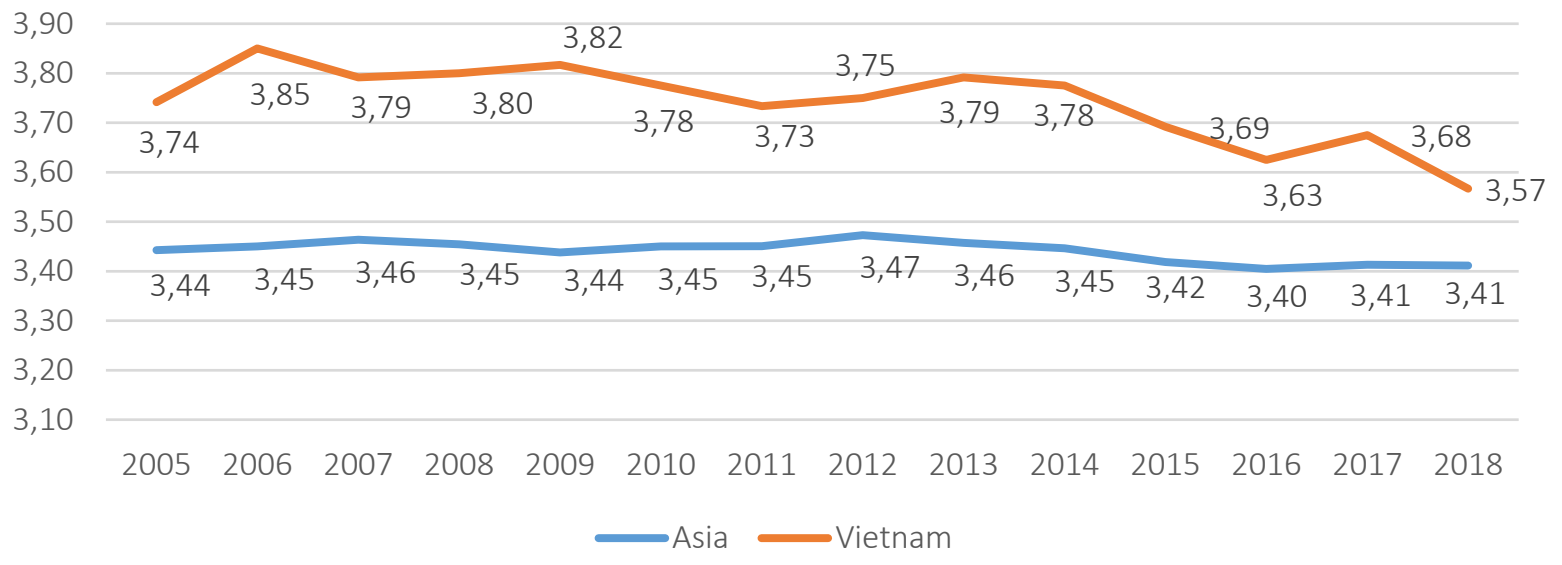

Figure 2. Institutional quality of Vietnam compared to the average of Asian countries presented as INS in the period 2005-2018 
Table 5. Comparison of economic growth between Vietnam and Asian countries

Source: Authors' elaboration.

\begin{tabular}{|c|c|c|c|c|c|c|}
\hline \multirow[b]{2}{*}{ Year } & \multicolumn{4}{|c|}{ The economic growth of Asian countries (48 countries) } & \multicolumn{2}{|c|}{ The economic growth of Vietnam } \\
\hline & $\begin{array}{l}\text { Quantile } \\
\text { of } 0.10\end{array}$ & $\begin{array}{l}\text { Quantile } \\
\text { of } 0.25\end{array}$ & $\begin{array}{l}\text { Quantile } \\
\text { of } 0.50\end{array}$ & $\begin{array}{l}\text { Quantile } \\
\text { of } 0.75\end{array}$ & $\begin{array}{l}\text { GDP per capita, taking } \\
\text { natural logarithms }\end{array}$ & Quantile \\
\hline 2005 & 6.4236 & 7.0521 & 8.0653 & 9.8832 & 6.9257 & 0.25 \\
\hline 2006 & 6.4970 & 7.0986 & 8.2276 & 9.9125 & 6.9838 & 0.25 \\
\hline 2007 & 6.5714 & 7.1167 & 8.2760 & 9.9332 & 7.0433 & 0.25 \\
\hline 2008 & 6.6205 & 7.1275 & 8.3394 & 9.9416 & 7.0888 & 0.25 \\
\hline 2009 & 6.6226 & 7.1491 & 8.3685 & 9.9351 & 7.1315 & 0.25 \\
\hline 2010 & 6.6847 & 7.2092 & 8.4346 & 9.9397 & 7.1838 & 0.25 \\
\hline 2011 & 6.7275 & 7.2473 & 8.5139 & 9.9358 & 7.2341 & 0.25 \\
\hline 2012 & 6.7727 & 7.2880 & 8.5907 & 9.9529 & 7.2748 & 0.25 \\
\hline 2013 & 6.8224 & 7.3362 & 8.6366 & 9.9629 & 7.3171 & 0.25 \\
\hline 2014 & 6.8734 & 7.3931 & 8.6701 & 9.9715 & 7.3647 & 0.25 \\
\hline 2015 & 6.8896 & 7.4560 & 8.6828 & 9.9829 & 7.4189 & 0.25 \\
\hline 2016 & 6.9306 & 7.5198 & 8.6867 & 9.9773 & 7.4688 & 0.25 \\
\hline 2017 & 6.9641 & 7.5768 & 8.6907 & 9.9566 & 7.5245 & 0.25 \\
\hline 2018 & 6.9898 & 7.6282 & 8.7002 & 9.9514 & 7.5830 & 0.25 \\
\hline
\end{tabular}

Table 6. CPIA index of Vietnam during the period 2005-2018

Source: Authors' elaboration based on data of the World Bank.

\begin{tabular}{|c|c|c|c|c|c|}
\hline Year & CPIA_ECON & CPIA_STRC & CPIA_SOCI & CPIA_PUBS & INS \\
\hline 2005 & 4.33 & 3.33 & 3.80 & 3.50 & 3.74 \\
\hline 2006 & 4.67 & 3.33 & 3.90 & 3.50 & 3.85 \\
\hline 2007 & 4.33 & 3.33 & 4.00 & 3.50 & 3.79 \\
\hline 2008 & 4.30 & 3.30 & 4.00 & 3.60 & 3.80 \\
\hline 2009 & 4.33 & 3.33 & 4.00 & 3.60 & 3.82 \\
\hline 2010 & 4.17 & 3.33 & 4.00 & 3.60 & 3.78 \\
\hline 2011 & 4.00 & 3.33 & 4.00 & 3.60 & 3.73 \\
\hline 2012 & 4.17 & 3.33 & 4.00 & 3.50 & 3.75 \\
\hline 2013 & 4.17 & 3.50 & 4.00 & 3.50 & 3.79 \\
\hline 2014 & 4.00 & 3.50 & 4.10 & 3.50 & 3.78 \\
\hline 2015 & 3.67 & 3.50 & 4.10 & 3.50 & 3.69 \\
\hline 2016 & 4.00 & 3.50 & 3.40 & 3.30 & 3.63 \\
\hline 2017 & 4.00 & 3.50 & 3.50 & 3.40 & 3.68 \\
\hline 2018 & 3.67 & 3.50 & 3.70 & 3.50 & 3.57 \\
\hline
\end{tabular}

Regarding improvement on institutions, Vietnam needs to continue to enhance social inclusion/ equity policy to reach the optimal threshold of CPIA_SOCI and maintain CPIA_PUBS at the threshold of 3.428 for maximum growth. It is noted that when public and institutional management CPIA_PUBS score exceeds the optimal threshold, institutions negatively affect economic growth, meaning that the improvement of institutional policy does not promote economic development. Vietnam's overall CPIA of 3.57, measured by INS variable, which is lower than the INS threshold of 3.62 found in the study, implying that Vietnam needs to improve appropriately its institutional quality in all respects to upgrade the overall av- erage CPIA score and remain at the threshold for maximum economic growth. Therefore, the study proposes several solutions to help improve the quality of institutions in Vietnam and contribute to economic growth relating to social inclusion/ equity as follows:

Firstly, gender equality in Vietnam should be addressed in the process of improving social inclusion/equity policies. The whole society needs to realize gender equality and Vietnamese women empowerment are objective demands for the whole country's development, in line with the requirements and responsibilities as a United Nations member to the international and regional com- 
munity. From that, Vietnamese women need to practice self-confidence to overcome gender stereotypes and upgrade to self-assertion. Secondly, Vietman is suggested to effectively manage budget by a clear financial mechanism so that it can intervene in time and avoid situations beyond control.
Finally, Vietman should issue policies to support initial investment, encourage effective investment in public services with various forms to increase capital mobilization, and provide favorable conditions for non-public establishments following the socio-oriented development.

\section{CONCLUSION}

Data was collected from 48 Asian countries between 2005 and 2018. The study investigates the relationship between institutions and economic growth to determine the factors that affect the expected level of economic growth using panel data regression (FGLS). The quantile regression method is applied for further analysis of the institutional impacts on economic growth at the different distribution of quantiles. The results show that expectation of economic growth is influenced by institutions via five different measurable variables of the CPIA indicator set. It is indicated that the level and direction of impacts of a single variable are different across various quantiles in which the degree of institutional impacts on economic growth decreases or reverses at higher percentiles while it is higher at countries with low quantiles of 0.1 and 0.25 , and its direction is always positive at 0.1 percentile.

In addition, the study examines the non-linear relationship between institutions and economic growth, thereby identifies the institutional thresholds affecting economic growth in Asia. The results indicate that there is an institutional threshold for economic growth to reach its highest level and exceeding it causes the switching impacts on economic growth. Vietnam has a growth rate of 0.25 quantile compared to 48 Asian countries during the study period, so Vietnam must focus on improving the quality of institutions in the field of social inclusion/equity as well as public sector management and institutions policies to promote economic development. With CPIA scores in 2018, Vietnam has not reached the optimal threshold at CPIA_SOCI or INS (overall CPIA) scores yet but exceeded the optimal threshold of the CPIA_PUBS index.

The results of the quantile regression method show that there is a strong classification of the level of institutional impact on single groups of countries subject to its relevant quantile of economic growth. Therefore, to achieve the desired growth rate of the country, policymakers should focus on the overall and individual impacts of the institutional quality on economic growth relevant to its economic performance so that appropriate improvements on institutional aspects, goals, and volumes are given to promote the country optimal economic growth. In the case of Vietnam, the government needs to maintain the quality of institutions in two aspects including (i) public sector management and institutions; and (ii) social inclusion/equity policy at the optimal threshold. Moreover, the Vietnamese government should keep upgrading the total average CPIA score as well as maintain at the threshold level so that maximum economic growth can be reached.

\section{AUTHOR CONTRIBUTIONS}

Conceptualization: Anh Hong Viet Nguyen.

Data curation: Hac Dinh Le.

Formal analysis: Hac Dinh Le.

Methodology: Anh Hong Viet Nguyen.

Project administration: Oanh Kim Thi Tran.

Resources: Hac Dinh Le, Anh Hong Viet Nguyen.

Software: Anh Hong Viet Nguyen.

Supervision: Oanh Kim Thi Tran, Anh Hong Viet Nguyen.

Writing - original draft: Hac Dinh Le.

Writing - review \& editing: Hac Dinh Le, Oanh Kim Thi Tran, Anh Hong Viet Nguyen. 


\section{REFERENCES}

1. Acemoglu, D., Naidu, S., Restrepo, P., \& Robinson, J. A. (2014). Democracy does cause growth. Journal of Political Economy, 127(1). Retrieved from https:// www.journals.uchicago.edu/doi/ abs/10.1086/700936? mobileUi=0\&

2. Acemoglu, D., Naidu, S., Restrepo, P., \& Robinson, J. A. (2015). Democracy, redistribution, and inequality. Handbook of income distribution, 2, 1885-1966. https:// doi.org/10.1016/B978-0-44459429-7.00022-4

3. Aisen, A., \& Veiga, F. J. (2013). How does political instability affect economic growth? (Working Papers No. 568). Central Bank of Chile. Retrieved from https://ideas. repec.org/p/chb/bcchwp/568.html

4. Alani, J. (2012). Effects of technological progress and productivity on economic growth in Uganda. Procedia Economics and Finance, 1, 14-23. https://doi.org/10.1016/S22125671(12)00004-4

5. Alexiou, C., Tsaliki, P., \& Osman, H. R. (2014). Institutional quality and economic growth: Empirical evidence from the Sudanese economy. Economic Annals, 59(203), 119-137. DOI:10.2298/ EKA1403119A

6. Barro, R. (1996). Determinants of economic growth: a crosscountry empirical study (Working Papers 5698). National Bureau of Economic Research. Retrieved from https://ideas.repec.org/p/ nbr/nberwo/5698.html

7. Beck, N., \& Katz, J. N. (1995). What to do (and not to do) with time-series cross-section data. American political science review,89(3), 634-647. https://doi. org/10.2307/2082979

8. Bernabe, M. D. (2017). Redefining inclusive growth in Asia (Briefing paper). Oxfam International. Retrieved from https://www. oxfam.org/en/research/redefininginclusive-growth-asia

9. Chong, C. Y. (2020). Nonlinear impact of institutional quality on economic performance within the comprehensive and progressive agreement for trans-pacific partnership. In Understanding Digital Industry ( $1^{\text {st }}$ ed.). Routledge. https://doi. org/10.1201/9780367814557-94

10. Di Vita, G. (2017). Institutional quality and the growth rates of the Italian regions: The costs of regulatory complexity. Papers in Regional Science, 97(4), 1057-1081. https://doi.org/10.1111/pirs.12290

11. Dias, J., \& Tebaldi, E. (2012). Institutions, human capital, and growth: The institutional mechanism. Structural Change and Economic Dynamics, 23(3), 300-312. https://doi.org/10.1016/j. strueco.2012.04.003

12. Dung, B. D., \& Phuong, P. T. (2009). Economic growth and social equity. VNU Journal of Science: Economics and Business, 25(2). (In Vietnamese). Retrieved from https://js.vnu.edu.vn/EAB/ article/view/1355

13. Erum, N., Hussain, S., \& Yousaf, A. (2016). Foreign direct investment and economic growth in SAARC countries. The Journal of Asian Finance, Economics, and Business, 3(4), 57-66. https://doi. org/10.13106/jafeb.2016.vol3. no4.57

14. Gani, A. (2011). Governance and growth in developing countries. Journal of Economic issues, 45(1), 19-40. https://doi.org/10.2753/ JEI0021-3624450102

15. Ha, L.T.N. (2016). The Relationship of Growth and Transparency in the Public Sector. VNU Journal Of Science: Economics And Business, 32(4). (In Vietnamese). Retrieved from https://js.vnu.edu.vn/EAB/article/ view/3876

16. Hodgson, G. M. (2004). The evolution of institutional economics. Routledge.

17. Ismihan, M., \& Metin-Ozcan, K. (2009). Productivity and growth in an unstable emerging market economy: The case of Turkey, 1960-2004. Emerging Markets Finance and Trade, 45(5), 4-18.
https://doi.org/10.2753/REE1540496X450501

18. Jaunky, V. C. (2013). Democracy and economic growth in SubSaharan Africa: a panel data approach. Empirical Economics, 45, 987-1008. Retrieved from https:// link.springer.com/article/10.1007/ s00181-012-0633-X

19. Kasper, W., \& Streit, M. E. (1999). Institutional economics. Edward Elgar Publishing.

20. Koenker, R., \& Bassett, G. (1978). Regression quantiles. Econometrica, 46(1), 33-50. https://doi.org/10.2307/1913643

21. Law, S. H., Lim, T. C., \& Ismail, N. W. (2013). Institutions and economic development: A Granger causality analysis of panel data evidence. Economic Systems, 37(4), 610-624. https://doi. org/10.1016/j.ecosys.2013.05.005

22. Loko, B., \& Diouf, M. A. (2009). Revisiting the determinants of productivity growth: What's new? (Working Paper). International Monetary Fund. Retrieved from https://www.imf.org/en/Publications/WP/Issues/2016/12/31/ Revisiting-the-Determinantsof-Productivity-Growth-Whatsnew-23354

23. Marakbi, R., \& Turcu, C. (2016). Corruption, institutional quality and growth: A panel smooth transition regression approach. Retrieved from https://www. semanticscholar.org/paper/ Corruption\%2C-InstitutionalQuality-and-Growth\%3A-a-Marakbi-Turcu/01a3b74fc2c65d1f8467f 150293ebe1daa0286a4

24. Miller, S. M., \& Upadhyay, M. P. (2002). Total factor productivity and the convergence hypothesis. Journal of Macroeconomics, 24(2), 267-286. https://doi.org/10.1016/ S0164-0704(02)00022-8

25. Nakabashi, L., Pereira, A. E. G., \& Sachsida, A. (2013). Institutions and growth: a developing country case study. Journal of Economic Studies, 40(5), 614-634. https://doi. org/10.1108/JES-09-2011-0111 
26. Ndjokou, I., \& Tsopmo, P. C. (2017). The effects on economic growth of natural resources in Sub-Saharan Africa: Does the quality of institutions matters? Economics Bulletin, 37(1), 248-263. Retrieved from https://ideas.repec. org/a/ebl/ecbull/eb-16-00550.html

27. Ngo, H. L. (2020). Improve financial institutions, promote economic development and strengthen international integration. Tap Chi Tai chinh. (In Vietnamese). Retrieved from https://tapchitaichinh.vn/ Chuyen-dong-tai-chinh/hoanthien-the-che-tai-chinh-thuc-daykinh-te-phat-trien-va-tang-cuonghoi-nhap-quoc-te-327068.html

28. Ngo, M. N., \& Nguyen, L. D. (2020). Economic growth, total factor productivity, and institution quality in low-middle income countries in Asia. The Journal of Asian Finance, Economics, and Business, 7(7), 251-260. https:// doi.org/10.13106/jafeb.2020.vol7. no7.251

29. Nguyen, C. H., \& Nguyen, T. T. (2014). Improving institutions and renew the mindset of socio-economic development in Vietnam. Journal of Development \& Integration, 17, 11-16. (In Vietnamese).

30. Nguyen, H. N. (2013). Institutional and economic institutional reform in Vietnam. Journal of Banking, 4, 7-13. (In Vietnamese).

31. Nguyen, V. P. (2013). Institutions and economic growth: Theory and practice. Journal of Economy \& Development, 191, 23-29. (In Vietnamese). Retrived from https://ktpt.neu.edu.vn/tap-chi/ so-191/nghien-cuu-trao-doi-238/ the-che-va-tang-truong-kinh-tely-thuyet-va-thuc-tien. 372833 . aspx

32. North, D. (2000). A Revolution in Economics (Chapter 4). In C. Menard (Ed.), Institutions, Contracts and Organizations. Cheltenham, UK: Edward Elgar Publishing.

33. North, D. C. (1990). Institutions, Institutional Change, and Economic performance. New York: Cambridge University Press
34. Ouoba, Y., \& Sawadogo, R. (2019). Natural resources effect on economic growth: The role of institutional quality. Journal of Policy Modeling. Retrieved from http://www.econmodels.com/uplo ad7282/18468cfe824ca4067afca26 e9de00b1c.pdf

35. Pham, D. L. (2017). Institution, aggregate factor productivity and economic growth: A study of developing countries (Thesis). HCMC University of Economics. (In Vietnamese).

36. Rigobon, R., \& Rodrik, D. (2005). Rule of law, democracy, openness, and income: Estimating the interrelationships1. Economics of transition, 13(3), 533-564. https://doi.org/10.1111/j.14680351.2005.00226.x

37. Rodrik, D., Subramanian, A., \& Trebbi, F. (2004). Institutions rule: the primacy of institutions over geography and integration in economic development. Journal of economic growth, 9(2), 131165. Retrieved from https://link. springer.com/article/10.1023/ B:JOEG.0000031425.72248.85

38. Salman, M., Long, X., Dauda, L., \& Mensah, C. N. (2019). The impact of institutional quality on economic growth and carbon emissions: Evidence from Indonesia, South Korea and Thailand. Journal of Cleaner Production, 241, 118331. https://doi.org/10.1016/j. jclepro.2019.118331

39. Siddiqui, D. A., \& Ahmed, Q. M. (2013). The effect of institutions on economic growth: A global analysis based on GMM dynamic panel estimation. Structural Change and Economic Dynamics, 24, 18-33. https://doi.org/10.1016/j. strueco.2012.12.001

40. Slesman, L., Baharumshah, A. Z. \& Ra'ees, W. (2015). Institutional infrastructure and economic growth in member countries of the Organization of Islamic Cooperation (OIC). Economic Modelling, 51, 214-226. https:// doi.org/10.1016/j.econmod.2015.08.008

41. Venard, B. (2013). Institutions, corruption and sustainable development. Economics Bulletin, 33(4), 2545-2562. https:// halshs.archives-ouvertes.fr/hal00874275/

42. Vianna, A. C., \& Mollick, A. V. (2018). Institutions: Key variable for economic development in Latin America. Journal of Economics and Business, 96, 42-58. https://doi.org/10.1016/j.jeconbus.2017.12.002

43. World Bank. World Bank Open Data. Retrieved from https:// data.worldbank.org/ (accessed on December 31, 2020). 